\title{
Purification and structural stability of a trypsin inhibitor from Amazon Inga cylindrica [Vell.] Mart. seeds
}

\author{
Leonardo A. Calderon', Humberto A. Almeida Filho², Rozeni C. L. Teles², \\ Francisco J. Medrano ${ }^{3}$, Carlos Bloch Jr ${ }^{4}$, Marcelo M. Santoro ${ }^{5}$ and Sonia M. Freitas ${ }^{2 \star}$
}

\footnotetext{
${ }^{1}$ Centro de Estudos de Biomoléculas Aplicadas a Medicina, Núcleo de Saúde, Universidade Federal de Rondônia, UNIR. Porto Velho, RO. Brazil;

${ }^{2}$ Laboratório de Biofísica, Depto de Biologia Celular, Universidade de Brasília, UnB. Brasília, DF. Brazil;

${ }^{3}$ Laboratório de Genômica e Expressão, Depto de Genética e Evolução, Universidade de Campinas, UNICAMP, Campinas, SP. Brazil;

${ }^{4}$ Laboratório de Espectrometria de Massa, Embrapa Recursos Genéticos e Biotecnologia. Brasília, DF. Brazil;

${ }^{5}$ Laboratório de Físico-Química de Proteínas, Depto de Bioquímica e Imunologia, Universidade Federal de Minas Gerais, UFMG. Belo Horizonte, MG. Brazil.
}

* Corresponding author: Campus Universitário Darcy Ribeiro, Asa Norte. Brasília, DF. Brazil. CEP: 70910-900; Tel.: +55 61 33072192; Fax: +55 61 33498411; e-mail: nina@unb.br

Received: 16 May 2010; Accepted: 11 July 2010.

\section{ABSTRACT}

Inga cylindrica Trypsin Inhibitor (ICTI) was purified as a single polypeptide chain by one step anion-exchange chromatography from a crude extract of Inga cylindrica (Vell.) Mart. seeds. ICTI is a $19.5 \mathrm{kDa}$ protein presenting a remarkable inhibitory activity against bovine trypsin (EC 3.4.21.4) $\left(K_{i}=4.3 \mathrm{nM}\right)$. Circular dichroism analysis revealed that this inhibitor is a $\beta$ type protein $(40.4 \%$ of $\beta$-strand; $24.6 \%$ of $\beta$-turn and $6.7 \%$ of $\alpha$-helix) in accordance with properties displayed in Kunitz type inhibitors. ICTI is a thermal stable protein within a wide range of $\mathrm{pH}\left(1.6\right.$ to 10.0) exhibiting highest stability at $\mathrm{pH} 7.0$ as indicated by $T_{m}$ of $70.0{ }^{\circ} \mathrm{C}$ and $\Delta G^{25}$ of $48.5 \pm 0.7 \mathrm{~kJ}_{\mathrm{mol}}{ }^{-1}$. The values of $\Delta G^{25}$ at pH $1.6\left(22.5 \pm 1.2 \mathrm{~kJ} \mathrm{~mol}^{-1}\right)$ and $\mathrm{pH} 10.0\left(31.5 \pm 1.0 \mathrm{~kJ} \mathrm{~mol}^{-1}\right)$ indicate a reduced structural stability of the protein under these conditions. This is likely to result from $\mathrm{pK}_{\mathrm{a}}$ differences of the acid and basic side chains reflecting the changes in the non-covalent interactions in the folded state.

Key words: Inga cylindrica [Vell.] Mart; Leguminosae; Mimosoideae; protease inhibitor; protein stability; trypsin inhibitor.

\section{INTRODUCTION}

Plant protease inhibitors (PIs) are small proteins, generally present in high concentrations in storage tissues (up to $10 \%$ of protein content), and also detectable in leaves in response to the attack from insects and pathogenic microorganisms (Ryan 1990). Pls' contribution to plant defense mechanisms relies on inhibition of proteases present in insect gut or produced by microorganisms, causing a reduction in the availability of amino acids necessary for their growth and development (De Leo et al. 2002). Pls are considered to be part of an array of constitutive and inducible chemical resistence that protect plants against herbivore predators (Ryan 1990; Gatehouse et al. 1999; Jouanin et al. 2000), and/or act as storage protein for the plant embryo (Xavier-Filho 1992), as regulators of endogenous proteolytic activity (Ryan 1990), as well as participating in mechanisms of programmed plant cell death (Solomon et al. 1999).

Pls from Leguminosae seeds have been classified under either Kunitz type or Bowman-Birk type on the basis of molecular mass and disulfide bond patterns (Ikenaka and Norioka 1986; Oliva and Sampaio 2008). Members of the Kunitz family have 
a molecular mass of approximately $18-26 \mathrm{kDa}$, with one or two polypeptide chains cross-linked by two or three disulfide bonds. These Pls usually have one reactive site, but recently, a secondary reactive site has been observed (Franco et al. 2002; Gomes et al. 2005; Teles et al. 2005). In contrast, members of the BowmanBirk PI family are smaller (6 to $15 \mathrm{kDa}$ ) and often present a conserved pattern of five to seven disulfide bonds that confer a compact and very stable tertiary structure with two opposite reactive loops (Lawrence and Koundal 2002). These Pls interact reversibly with proteinases forming stoichiometric complexes and competitively influencing the catalytic activity (Radisky et al. 2004). Pls have been studied as model systems for elucidating proteinase inhibition mechanisms, as well as the study of proteinprotein associations (Oliva and Sampaio 2008).

Bowman-Birk and Kunitz Pls have been long used in the development of transgenic plants by the expression of heterologous inhibitors in order to improve resistance against pests and pathogens that are responsible for severe impacts on agriculture production (Lopes et al. 2004; Zavala et al. 2004). Moreover, many of these Pls have often been used as an effective insecticide against several pest insect species, including dipterans as Ceratitis capitata (Gomes et al. 2005; Oliveira et al. 2007), lepidopterans such Alabama argillacea (Oliveira et al. 2007), Anagasta kuehniella (Macedo et al. 2003), Heliothis zea (Broadway and Duffey 1986), Lucila cuprina (Reed et al. 1999), Manduca sexta (Johnson et al. 1989), Plodia interpunctella (Oliveira et al. 2007), Spodoptera litura (Yeh et al. 1997), and coleopterans such Anthonomus grandis (Franco et al. 2003, 2004), Callosobruchus maculatus (Gomes et al. 2005; Oliveira et al. 2007), Zabrotes subfasciatus (Oliveira et al. 2007), and others (Araujo et al. 2005).

Beyond the well known role of seeds Pls in plant defense againstherbivory, it was postulated that these proteins can regulate plant cell proteolysis by inhibition of endogenous proteases and thus control protein turnover and metabolism (Ryan 1989). In fact, it had already been demonstrated that some Pls play a crucial role in seed development (Sin et al. 2006).

In this paper, we report the purification and partial structural characterization of a $\mathrm{Pl}$ with molecular mass of $19.5 \mathrm{kDa}$ from Amazon Inga cylindrica seeds. I. cylindrica is a Leguminosae belonging to the Mimosoideae family. It is a species distributed from southeast Costa Rica to the Brazilian Amazon, as well as some central areas and coastal regions (Pennington 1997). Its fruit represent an important alimentary source for the Amazon primate population which in turn disperse the seeds (Andresen 2002). In this context, the purification and characterization of this new PI can also represent a first step in exploring some important aspects of seed development of this Amazon species.

\section{MATERIAL AND METHODS}

Purification of Inga cylindrica inhibitor: One hundred grams of seeds were crushed and stirred for 1 minute in acetone at $-20^{\circ} \mathrm{C}$ in order to remove its lipid content. A part of this material (ten grams of pulverized seeds) was homogenized in $100 \mathrm{~mL}$ of $150 \mathrm{mM} \mathrm{NaCl}$ and stirred for 16 hours, at $4^{\circ} \mathrm{C}$. The extract was centrifuged at $8.000 \mathrm{~g}$ for 30 min. The resulting supernatant was dialyzed against water and lyophilized. The purification of ICTI was performed by anionexchange chromatography in DEAE-Celulose column $(8.0 \mathrm{x}$ $2.5 \mathrm{~cm}$ i.d.) equilibrated with $20 \mathrm{mM}$ Tris-HCl buffer (pH 8.0). A sample of $100 \mathrm{mg}$ of $l$. cylindrica crude extract eluted in 5 $\mathrm{mL}$ of $20 \mathrm{mM}$ Tris- $\mathrm{HCl}$ buffer ( $\mathrm{pH}$ 8.0) was applied into the column. Elution was carried out at a flow rate of $2.5 \mathrm{~mL}$. $\mathrm{min}^{-1}$ with increasing concentrations of $\mathrm{NaCl}(0$ to $1.0 \mathrm{M})$. Fractions were pooled and assayed to inhibitory activity against bovine trypsin according to Erlanger et al. 1961.

Bovine protease inhibition assays: The inhibitory activities of the crude extracts and the purified ICTI against bovine trypsin (EC 3.4.21.4) and bovine $\alpha$-chymotrypsin (EC 2.4.21.1) were performed as described by Erlanger et al. (1961) using the chromogenic substrates $\mathrm{N}$-benzoyl-DL-arginine-p-nitroanilide (BAPNA) and N-glutaryl-L-phenylalanine p-nitroanilide (GPNA), respectively. Briefly, $100 \mu \mathrm{L}$ of ICTI at a concentration of 300 $\mu \mathrm{g} \cdot \mathrm{mL}^{-1}$ in water were incubated with $100 \mathrm{~mL}$ of $0.8 \mathrm{mg} \cdot \mathrm{mL}^{-1}$ $\alpha$-chymotrypsin or $100 \mathrm{~mL}$ of $0.64 \mathrm{mg}^{-\mathrm{mL}^{-1}}$ trypsin, at $25^{\circ} \mathrm{C}$ for 15 minutes. After that, $500 \mathrm{~mL}$ of $0.43 \mathrm{mg} \cdot \mathrm{mL}^{-1}$ BAPNA in 50 $\mathrm{mM}$ Tris- $\mathrm{HCl}, 20 \mathrm{mM} \mathrm{CaCl}_{2}$ buffer (pH 8.2) for trypsin assay or $0.40 \mathrm{mg} \mathrm{mL}^{-1} \mathrm{GPNA}$ in $50 \mathrm{mM}$ Tris- $\mathrm{HCl}, 20 \mathrm{mM} \mathrm{CaCl}_{2}$ buffer (pH 7.6) for chymotrypsin assay were added. Following a reaction time of 10 minutes, $100 \mu \mathrm{L}$ of $30 \%$ acetic acid was added in order to stop the reactions. The relative enzymatic activities were evaluated by the liberation of $p$-nitroanilide which was measured at $410 \mathrm{~nm}$ with a Hitachi U-1100 spectrophotometer. The residual activities of the enzymes, in the presence of the inhibitor were estimated considering the free enzyme activity to be $100 \%$. The obtained values are an average of three independent measurements. Inhibition curves were obtained by plotting decreasing relative activities of the protease versus ICTI concentration. Inhibition constant of the enzyme-inhibitor 
complex, $K_{i}$, was calculated from the fitted inhibition curve following the procedure described by Morrison, 1982, using the GRAFIT program version 3 (Erithacus software Ltd.).

Molecular mass determinations: Molecular mass of the proteins present in the crude extracts and purified ICTI were determined using a Voyager-DE STR from PerSeptive Biosystems. Samples were prepared for Matrix Assisted Laser Desorption Ionization Time of Flight (MALDI-TOF) analysis by mixing equal volumes $(9 \mu \mathrm{L})$ of a protein solution $(5 \mathrm{pmol})$ and $25 \mathrm{mg} \mathrm{mL}^{-1}$ ferulic acid (trans-4-Hydroxy-3-methoxycinnamic acid) in acetone (matrix solution). The mixture was vigorously stirred for 30 seconds in a Vortex Genie 2. One $\mu \mathrm{L}$ of each solution was applied to a MALDI sample plate and allowed to dry at room temperature. The instrument was operated in linear mode with delayed extractions on. Ions were generated by irradiation with a nitrogen laser with fixed wavelength on $337 \mathrm{~nm}$. Ions were accelerated with a voltage of $25 \mathrm{kV}$ and delay of $500 \mathrm{~ns}$. Signals were captured at $500 \mathrm{MHz}$ and the obtained data was processed, using the GRAMS V.4.03 program and Galatic software. Spectra were obtained through internal calibration by using the Sequazyme molecular mass standards set out by PerSeptive Biosystems.

Number of polypeptide chains estimation by MALDITOF and electrophoresis: In order to determine the number of polypeptide chain content, samples were incubated with 50 $\mathrm{mL}$ of $50 \mathrm{mM} \mathrm{NH}_{4} \mathrm{HCO}_{3}$ and $1.5 \mathrm{~mL}$ of $50 \mathrm{mM}$ dithiothreitol (DTT) for 30 minutes. After incubation, molecular mass was determined by MALDI-TOF Mass Spectrometry and differences in the molecular mass of the native and reduced protein were analyzed. The approximate molecular mass of ICTI was calculated using 13\% SDS-PAGE (Laemmli 1970) in reducing conditions, employing molecular mass standards purchased from Sigma: bovine serum albumin (66,200 Da), ovalbumin (45,000 Da), glyceraldehyde 3-phosphate dehydrogenase $(36,000 \mathrm{Da})$, carbonic anhydrase $(29,000 \mathrm{Da})$, trypsinogen (24,000 Da), soybean trypsin inhibitor (20,100 Da) and $\alpha$-alactoalbumin (14,200 Da). For protein detection, gels were stained with $0.01 \%$ Coomassie blue in $\mathrm{MeOH} / \mathrm{H}_{2} \mathrm{O}(4 / 6)$ and $\mathrm{HOAc} / \mathrm{H}_{2} \mathrm{O}(1 / 9)$.

Fluorescence emission analysis: For the emission fluorescence measurement at temperatures ranging from $25^{\circ} \mathrm{C}$ to $95^{\circ} \mathrm{C}$, samples of protein in $20 \mathrm{mM}$ MOPS buffer (pH 7.0), 20 $\mathrm{mM}$ sodium citrate buffer ( $\mathrm{pH} 1.6), 20 \mathrm{mM}$ sodium citrate buffer (pH 3.8) and $20 \mathrm{mM}$ glycine-NaOH buffer (pH 10.0) were used.
Emission spectra were recorded at $300-400 \mathrm{~nm}$ in a $1 \times 1 \mathrm{~cm}$ length thermostated quartz cell with a Peltier-type temperature controller, after $295 \mathrm{~nm}$ excitation, with $5 \mathrm{~nm}$ bandwidth for both excitation and emission, using a JASCO FP-777 fluorescence spectrophotometer. The transition curves were obtained using centered $359 \mathrm{~nm}$ emission bands and the protein fraction present in the folded $\left(f_{N}\right)$ and unfolded conformation $\left(f_{U}\right)$. The $f_{U}$, equilibrium constants (Keq), and Gibbs free energy $(\Delta G)$ were calculated using the following equations:

$f_{U}=\left(y_{F}-y\right) /\left(y_{F}-y_{U}\right)$

$K$ eq $=[\mathrm{U}] /[\mathrm{N}]=f_{\mathrm{U}} /\left(1-f_{\mathrm{U}}\right)=\left(y_{\mathrm{F}}-y\right) /\left(y-y_{\mathrm{U}}\right)$

$\Delta G=-R T \ln K e q=-R T \ln \left[\left(y_{\mathrm{F}}-y\right) /\left(y-y_{\mathrm{U}}\right)\right]$

where $y_{\mathrm{F}}$ and $y_{\cup}$ represent the amount of $y$ in the folded and unfolded states, respectively. These data were fitted according to Eq. 4 considering the van't Hoff approximation (Eq. 5):

$$
\begin{aligned}
& \text { Yobs }=\frac{(Y d+M d \cdot T) \exp [(\Delta \mathrm{S} / \mathrm{R})-(\Delta \mathrm{H} / R T)]+(\mathrm{Y} n+M n \cdot T)}{1+\exp [(\Delta \mathrm{S} / \mathrm{R})-(\Delta \mathrm{H} / R T)} \\
& \operatorname{Ln} K e q=(\Delta \mathrm{S} / \mathrm{R})-(\Delta \mathrm{H} / \mathrm{R}) \cdot(1 / T)
\end{aligned}
$$

where $\mathrm{Keq}$ is the experimentally observed equilibrium constant, $T$ is the temperature in Kelvin $(\mathrm{K}), \Delta H$ is the slope (the van'T Hoff change in enthalpy) and $\Delta S$ is the intersection from the linear regression (the change in entropy). In Eq. 4, these parameters have the same meaning. Additionally, Yobs is the experimentally observed spectroscopic data, $Y n$ and $M n$ represent the intercept and slope of the pretransition straight line, respectively, whereas $Y d$ and $M d$ represent the intercept and slope of the posttransition straight line, respectively.

The correspondent stability at $25^{\circ} \mathrm{C}\left(\Delta \mathrm{G}^{25}\right)$ was estimated from the Gibbs-Helmholtz equation (Eq. 6), which is the result of the approximation of the change in heat capacity value that accompanies protein unfolding $\left(\Delta \mathrm{C}_{\mathrm{p}}\right)$ to zero, seeing the values of $\Delta H_{(t)}$ and $\Delta S_{(t)}$ constant in the temperature range where unfolding occurs.

$\Delta G_{(t)}=\Delta H_{m}\left(1-T / T_{m}\right)$

The transition temperature $T_{m}$ corresponding to the midpoint of the thermal unfolding curve was calculated from the $\Delta G$ versus $T$ plot, for $\Delta G=0\left(\Delta G=0=\Delta H_{m}-T_{m}\right.$ $\left.\Delta S_{m}\right)$. The slope of this plot at $T_{m}$ corresponds to $\Delta S_{m}$ and the enthalpy at $T_{m}$ is $\Delta H_{\mathrm{m}}=T_{m} \Delta S_{m}$ (Santoro, Bolen, 1992). 
Circular dichroism spectrum analysis: Far-UV (190$260 \mathrm{~nm}$ ) circular dichroism measurements were carried out on a JASCO J-815 (Jasco, Tokyo, Japan) spectropolarimeter equipped with a Peltier type temperature controller and thermostatized cuvette cell linked to a thermostatic bath. Spectra were recorded in $0.1 \mathrm{~cm}$ path length quartz cells at a protein concentration of $300 \mu \mathrm{g} \cdot \mathrm{mL}^{-1}$ in $50 \mathrm{mM}$ MOPS buffer (pH 7.0). Five consecutive scans were accumulated and the average spectrum was stored. The observed ellipticities were converted into the molar ellipticities [ $\theta$ ] based on a mean molecular mass per residue of $112 \mathrm{Da}$. Data was corrected for the baseline contribution of MOPS buffer.

Secondary structure contents were estimated from the CD curves adjustments using the program CDNN (Böhm, 1997), considering the database that resulted on total sum of secondary structures closest to $100 \%$.

\section{RESULTS AND DISCUSSION}

Purification of $I$. cylindrica trypsin inhibitor (ICTI): The $\mathrm{PI}$ from the Inga cylindrica seed crude extract was identified by trypsin and chymotrypsin inhibitory activity assays. In order to purify the trypsin inhibitor, the dialyzed and lyophilized crude extract was submitted to an anion-exchange chromatography on DEAE-Cellulose. The elution with $\mathrm{NaCl}$ gradient yielded ten peaks related to protein fractions. The proteins presenting trypsin inhibitory activity was eluted in the fifth (non-retained), eighth (80 mM NaCl) and ninth (120 mM NaCl) fractions (Figure
1). The active fractions were pooled and analyzed by Coomassie Blue-stained SDS-PAGE and MALDI-TOF mass spectrometry. Analysis reveals that the fractions $\mathrm{V}$ and $\mathrm{IX}$ present proteins ranging from 6 to $20 \mathrm{kDa}$. The purification of the trypsin inhibitor was achieved in the fraction VIII, which presented a protein with a molecular mass of 19,465.19 Da $[\mathrm{M}+\mathrm{H}]^{+}$(Figure 2). This fraction was pooled and analyzed by SDS-PAGE in the presence of the reducing agent. After Coomassie blue staining, a single band with an apparent molecular mass of $20 \mathrm{kDa}$ was observed (Figure 2 inset), showing the presence of a single polypeptide chain. This result was confirmed by mass spectrometry analysis of the protein reduced with DTT. This protein was named Inga cylindrica Trypsin Inhibitor (ICTI).

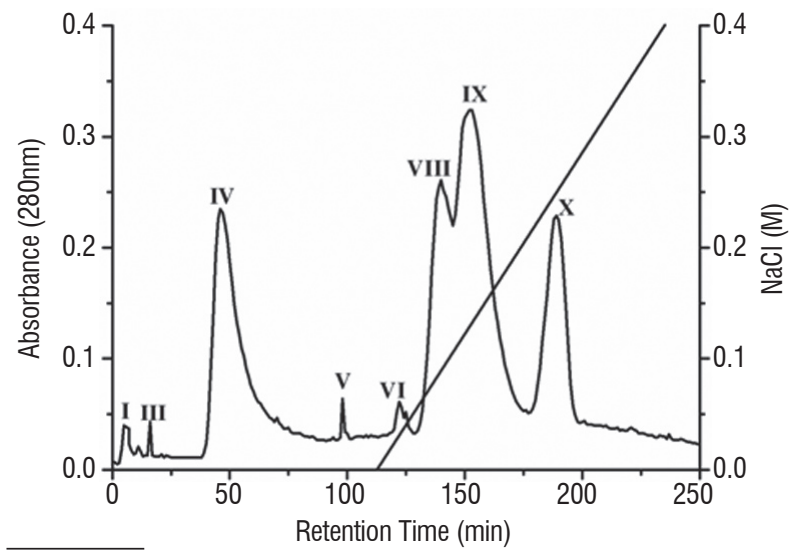

Figure 1. DEAE-Celulose ion exchange chromatography showing four mainly peaks (IV, VII, IX and X). The inhibitors were eluted with $20 \mathrm{mM}$ Tris-HCl buffer (pH 8.0) in a crescent and linear salt gradient (0-1 M) NaCl. The peaks IV and VIII correspond to eluted proteins with inhibitory activity against bovine trypsin.

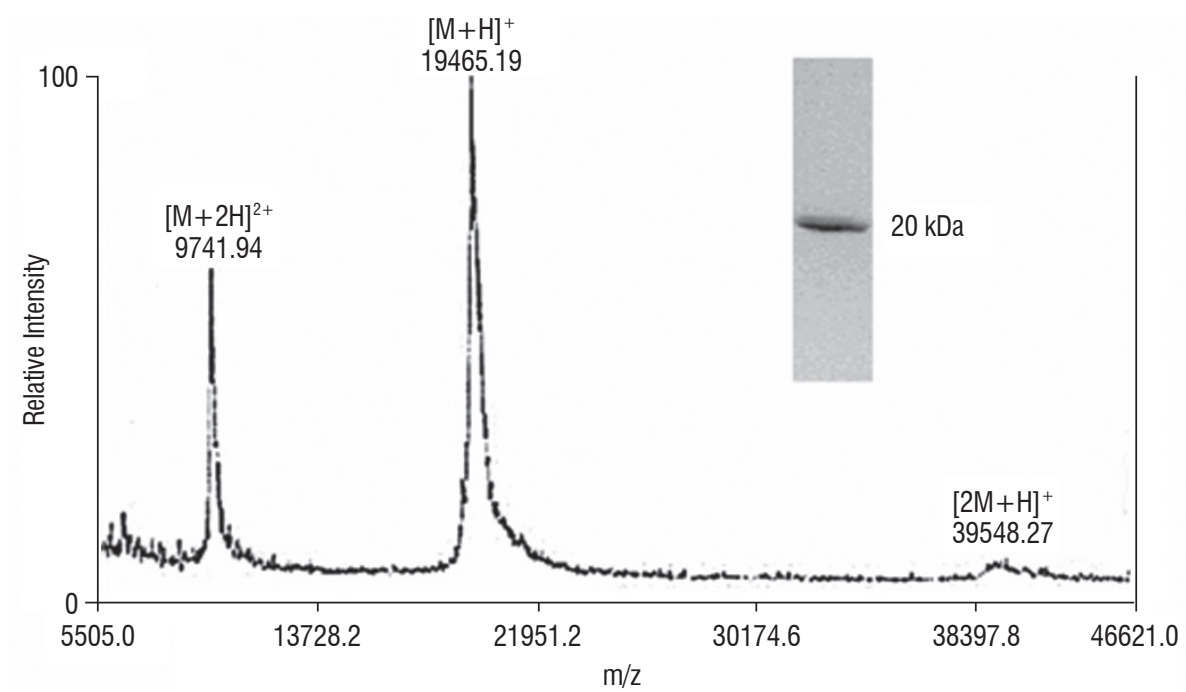

Figure 2. MALDI-TOF MS analysis performed on peak VIII sample (pure ICTI) resulted in a molecular mass value $\left([\mathrm{M}+\mathrm{H}]^{+}\right.$) value of $19,465.19$, a $[\mathrm{M}+2 \mathrm{H}]^{2+}$ of $9,741.94$, and a $[2 \mathrm{M}+\mathrm{H}]^{+}$of $39,548.27$. Fig. 2 inset, $13 \%$ SDS-PAGE analysis of ICTI. Protein band was stained with Coomassie blue R-250. 
Inhibitory properties and dissociation constant determination: The inhibitory activity of ICTI against bovine trypsin (EC 3.4.21.4) and bovine chymotrypsin (EC 2.4.21.1) was determined by measuring the hydrolytic activity toward BAPNA and GPNA, respectively. The ICTI inhibited trypsin at a molar ratio of 1:1 but did not show any significant inhibition against $\alpha$-chymotrypsin. The dissociation constant $\left(K_{i}\right)$ value of ICTI was calculated using the inhibition curve according to the Morrison method. The dissociation constant $\left(K_{i}\right)$ value was found to be $4.3 \mathrm{nM}$ which clearly indicates that ICTI is a potent and competitive inhibitor of bovine trypsin (Figure 3).

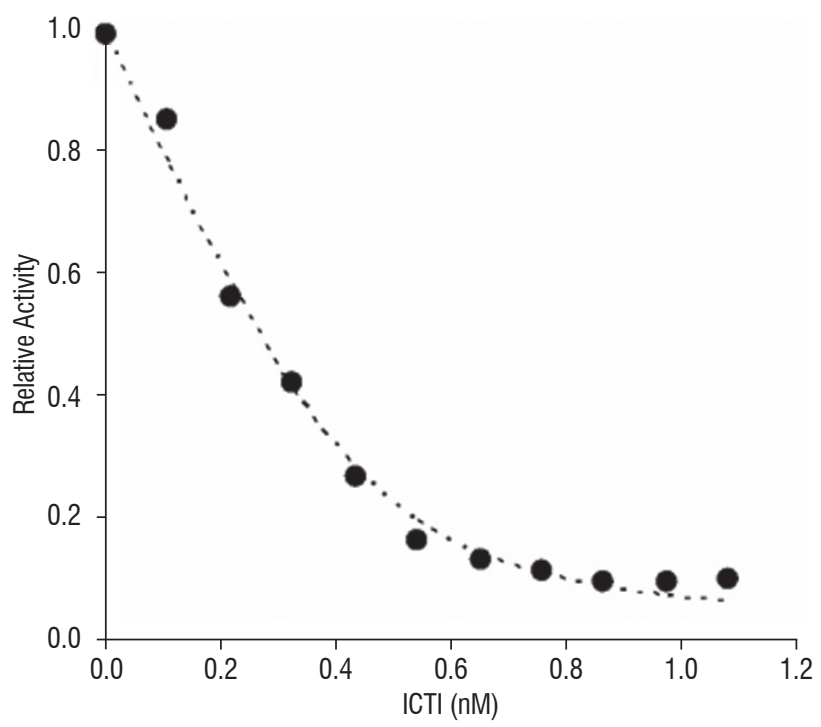

Figure 3. Inhibitory activity of ICTI against trypsin. Residual activities of trypsin were measured at $25^{\circ} \mathrm{C}$ with BAPNA at pH $8.2\left(K_{i}=4.3 \mathrm{nM}\right)$.

Stability studies: Fluorescence studies at increasing temperatures demonstrated the thermal stability of ICTI structure. The fluorescence spectra were recorded at 300-400 $\mathrm{nm}$ with temperatures ranging from 25 to $95{ }^{\circ} \mathrm{C}$ at different pHs (1.6, 3.8, 7.0 and 10.0). The fluorescence intensities at $359 \mathrm{~nm}$ were used to obtain the unfolding curves assuming a two state process (Figure 4). The thermodynamic parameters were obtained from the linear fitted curves in accordance with van't Hoff approximation (Figure 4 inset). The data suggest that the thermal stability of this $\mathrm{PI}$ is clearly dependent on $\mathrm{pH}$. The $\Delta G^{25}$ value decreases in both extreme pHs, showing the major value at $\mathrm{pH} 7.0$ with $\Delta \mathrm{G}^{25}$ of $48.5 \mathrm{~kJ}$. mol ${ }^{-1}$ (Table 1). This result is in accordance with the most cases of thermostable globular proteins with $\Delta \mathrm{G}^{25}$ ranging from 21.0 to $63.0{\mathrm{~kJ} . \mathrm{mol}^{-1}}^{-1}$ (Pace 1990).

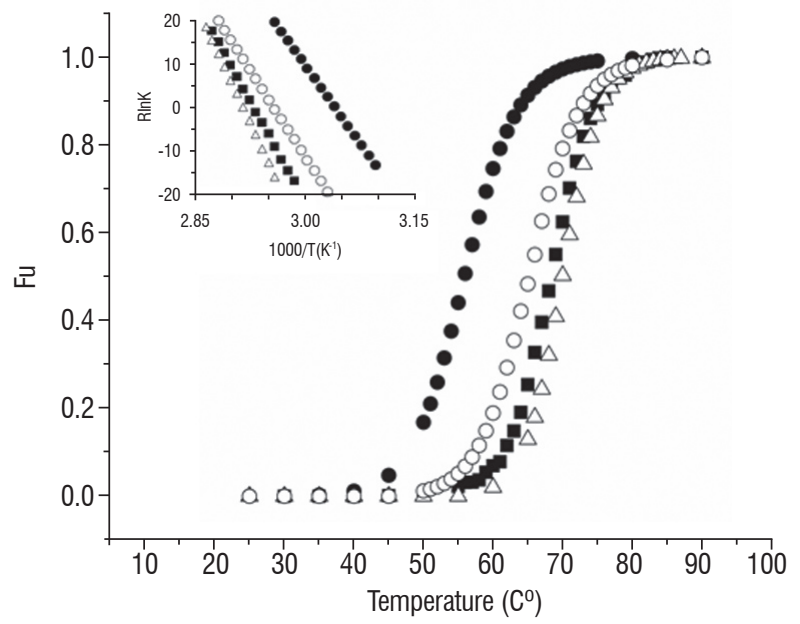

Figure 4. Heat-induced unfolding curves of ICTI according to Eq. 4 (see Materials and Methods) obtained at pH 1.6 (solid circles); 3.8 (solid squares); 7.0 (open triangles) e 10.0 (open circles). These data are calculated considering the decrease of fluorescence intensity at $359 \mathrm{~nm}$. Fig. 4 inset, van't Hoff Plot (Eq. 5). The estimated thermodynamic parameters derived from these analysis are presented in Table 1.

Table 1. Thermodynamic parameters for the thermal unfolding of ICTI obtained from fluorescence measurement at different $\mathrm{pH}$ values.

\begin{tabular}{ccccc}
\hline $\mathbf{p H}$ & $\boldsymbol{T}_{\mathrm{m}}\left({ }^{\circ} \mathbf{C}\right)$ & $\boldsymbol{\Delta} \mathbf{G}^{25}\left(\mathbf{k J} \cdot \mathbf{m o l}^{-1}\right)$ & $\boldsymbol{\Delta H}_{\mathrm{m}}\left(\mathbf{k J} \cdot \mathbf{m o l}{ }^{-1}\right)$ & $\Delta \mathbf{S}_{\mathrm{m}}\left(\mathbf{k J} \cdot \mathbf{m o l}^{-1} \cdot \mathbf{K}^{-1}\right)$ \\
\hline 1.6 & 55.9 & $22.5 \pm 1.2$ & $239.6 \pm 9.8$ & $0.728 \pm 0.029$ \\
3.8 & 68.3 & $38.7 \pm 0.3$ & $305.0 \pm 2.2$ & $0.893 \pm 0.006$ \\
7.0 & 70.0 & $48.5 \pm 0.7$ & $369.7 \pm 12.0$ & $1.074 \pm 0.035$ \\
10.0 & 65.1 & $31.5 \pm 1.0$ & $265.3 \pm 9.8$ & $0.784 \pm 0.029$ \\
\hline
\end{tabular}

CD spectroscopy: Far-UV CD spectroscopy study (250$190 \mathrm{~nm}$ wavelength range) was carried out in order to estimate the secondary structure content. The ajusted $C D$ spectrum of the native ICTI with a negative band at approximately $201 \mathrm{~nm}$ (Figure 5 ) showed that this $\mathrm{PI}$ is a $\beta$ protein type composed by $40.4 \%$ of $\beta$-strand, $24.6 \% \beta$-turn, $33 \%$ of unordered and $6.7 \%$ of $\alpha$-helix secondary structures. This results are in accordance with most trypsin inhibitors particularly the Kunitz type inhibitors that are predominantly structurally organized in $\beta$-strand with little helical content (Azarkan et al. 2006; Chaudhary et al. 2008). 


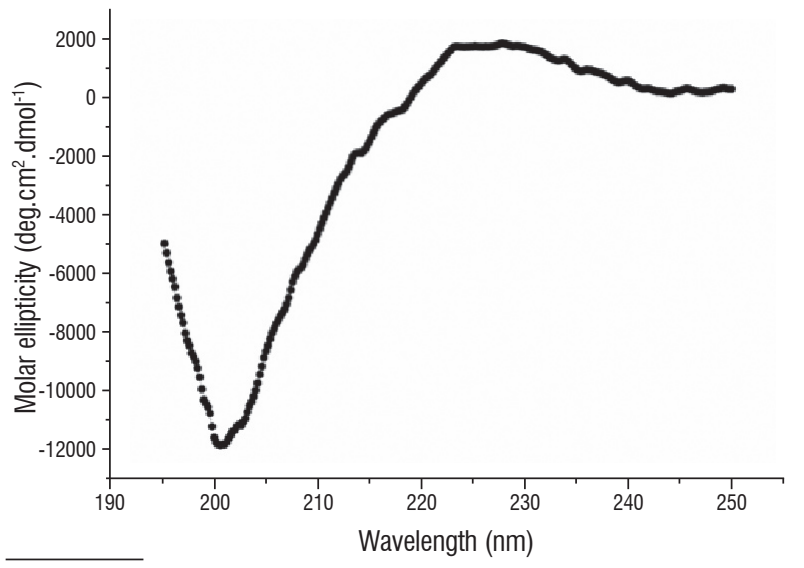

Figure 5. Far-UV CD spectrum of the ICTI. The deconvoluted spectrum results in a predominance of $\beta$-strand (40.4\%) and unordered secondary structure (33\%) presenting a low content of $\alpha$-helix structure $(6.7 \%)$.

\section{CONCLUSIONS}

Species-rich genera such as the Inga (Leguminosae - Mimosoideae), which is composed of 300 species is one important characteristic of the Amazon biodiversity (Richardson et al. 2001; Bermingham and Dick 2001). Amazonian leguminosae seeds are an under explored source of new PIs, with a few number of species researched (Calderon 2004). To date, four Pls have been described from Inga seeds (i.e. IUCI-1, IUCI-2, IUCTI from I. umbratica and ILTI from I. laurina) (Calderon et al. 2001, 2005; Macedo et al. 2007). Results show a new PI named Inga cylindrica Trypsin Inhibitor (ICTI) that is a single thermal stable polypeptide chain with a molecular mass of $19.5 \mathrm{kDa}$, which differs from the majority of other Kunitz inhibitors purified from the Mimosoideae species that have two polypeptide chains. ICTI displayed a remarkable thermal stability at pH 7.0 as indicated by $T_{m}$ of $70.0^{\circ} \mathrm{C}$ and $\Delta \mathrm{G}^{25}$ of $48.5 \mathrm{~kJ} \mathrm{~mol}^{-1}$. CD analyses of ICTI revealed that it is an $\beta$-strand type protein in accordance with well-characterized Kunitz type Pls. The $K_{i}$ value of $4.3 \mathrm{nM}$ demonstrated a high affinity between bovine trypsin (EC 3.4.21.4). However, in order to place ICTI under the Kunitz family of Pls possessing a single disulfide bridge and its role in seed development, complete amino acid sequencing of the inhibitor and further experiments need to be carried out.

Acknowledgements: Part of this study was supported by Coordenação de Aperfeiçoamento de Pessoal de Nível Superior (CAPES), Conselho Nacional de Pesquisa
(CNPq - Grant S.M.F. 305022/2009-1) and Fundação de Empreendimentos Tecnológicos (FINATEC).

\section{REFERENCES}

Andresen E (2002) Primary seed dispersal by red howler monkeys and the effect of defecation patterns on the fate of dispersed seeds. Biotropica 34:261-272.

Araujo CL, Bezerra IWL, Oliveira AS, Moura FT, Macedo LLP, Gomes CEM, Barbosa AEAD, Macedo FP, Souza TMS, Franco OL, Bloch-Jr C, Sales MP (2005) In vivo bioinsecticidal activity toward Ceratitis capitata (Fruit fly) and Callosobruchus maculatus (Cowpea weevil) and in vitro bioinsecticidal activity toward different orders of insect pests of a trypsin inhibitor purified from tamarind tree (Tamarindus indica) seeds. J. Agric. Food Chem. 53: 4381-4387.

Azarkan M, Dibiani R, Groomaghtigh E, Raussens V, Baeyens-Volant D (2006) The papaya Kunitz-type trypsin inhibitor is a highly stable b-sheet glycoprotein. Biochim. Biophys. Acta 1764:1063-1072.

Bermingham E, Dick C (2001) Rapid diversification of a species-rich genus of neotropical rain forest trees. Science 293:2214-2216.

Böhm G (1997) CDNN: CD spectra deconvolution software version 2.1, University of Halle-Wittenberg: Halle.

Broadway RM, Duffey SS (1986) Plant proteinase inhibitor: mechanism of action and effect on the growth and digestive physiology of larval Heliothis zea and Spodoptera exiqua. J. Insect Physiol. 32:827-833.

Calderon LA (2004) Leguminosas amazônicas: Caracterização de inibidores de proteinases serínicas. Brasília, Universidade de Brasília. PhD thesis.

Calderon LA, Teles RCL, Leite JRSA, Bloch Jr C, Astolfi-Filho S, Freitas SM (2001) Serine protease inhibitors from Amazon Leguminosae seeds: Purification and preliminary characterization of two chymotrypsin inhibitors from Inga umbratica. Prot. Pep. Letters 8: 485-493.

Calderon LA, Teles RCL, Leite JRSA, Franco OL, Grossi-de-Sá MF, Medrano FJ, Bloch Jr C, Freitas S.M. (2005) Purification of a $6.5 \mathrm{kDa}$ protease inhibitor from Amazon Inga umbratica seeds effective against serine proteases of the Boll Weevil Anthonomus grandis. Prot. Pep. Letters 12:583-587.

Chaudhary NS, Shee C, Islam A, Ahmad F, Yernool D, Kumar P, Sharma AK (2008) Purification and characterization of a trypsin inhibitor from Putranjiva roxburghii seeds. Phytochemistry 69:2120-2126.

Chevreuil LR, Gonçalves JFC, Bariani A, Rodrigues JVFC, Pando SC (2009) Detecção de inibidores de tripsina e atividade hemaglutinante em sementes de leguminosas arbóreas da amazônia. ACTA Amaz. 39(1):199-206.

Condit R, Pitman N, Leigh Jr EG, Chave J, Terborgh J, Foster RB, Aguilar PNS, Valencia R, Villa G, Muller-Landau HC, Losos E, Hubbell SP (2002) Betadiversity in tropical forest trees. Science 295:666-669.

De Leo F, Volpicella M, Licciulli F, Liuni S, Gallerani R, Ceci LR (2002) PLANTPls: a database for plant protease inhibitors and their genes. Nucleic Acids Res. 30(1):347-348.

Erlanger BF, Kokowsky N, Cohen E (1961) The preparation and properties of two new chromogenic substrates of trypsin. Arch. Biochem. Biophys. 95:271-278.

Franco OL, Dias SC, Magalhaes CP, Monteiro ACS, Bloch-Jr C, Melo FR, Oliveira-Neto OB, Monnerat RG, Grossi-de-Sa MF (2004) Effects of soybean Kunitz trypsin inhibitor on the cotton boll weevil (Anthonomus grandis). Phytochemistry 65:81-89.

Franco OL, Grossi-de-Sa MF, Sales MP, Mello LV, Oliveira AS, Rigden DJ (2002) Overlapping binding sites for trypsin and papain on a Kunitz-type proteinase inhibitor from Prosopis juliflora. Prot. Struc. Func. Gen. 49:335-341.

Franco OL, Santos RC, Batista JAN, Mendes ACM, Araujo MAM, Monnerat RG, Grossi-de-Sa MF, Freitas SM (2003) Effects of black-eyed pea trypsin/ 
chymotrypsin inhibitor on proteolytic activity and on development of Anthonomus grandis. Phytochemistry 63:343-349.

Gatehouse AMR, Norton E, Davison GM, Babbe SM, Newell CA, Gatehouse JA (1999) Digestive proteolytic activity in larvae of tomato moth, Lacanobia oleracea; effects of plant protease inhibitors in vitro and in vivo. J. Insect Physiol. 45:545-558.

Gomes CEM, Barbosa AEAD, Macedo LLP, Pitanga JCM, Moura FT, Oliveira AS, Moura RM, Queiroz AFS, Macedo FP, Andrade LBS, Vidal MS, Sales MP (2005) Effect of trypsin inhibitor from Crotalaria pallida seeds on Callosobruchus maculatus (cowpea weevil) and Ceratitis capitata (fruit fly). Plant Physiol. Biochem. 43:1095-1102.

Ikenaka T, Norioka S (1986) Bowman-Birk family serine proteinase inhibitors. In: Barret AJ, Salvesen G (eds), Protease Inhibitor, pp. 361-374. Elsevier, Amsterdam.

Johnson R, Narvaez J, An GH,Ryan C (1989) Expression of proteinase inhibitor-I and inhibitor-II in transgenic tobacco plants-effects on natural defense against Manduca-Sexta larvae. Proc. Natl. Acad. Sci. USA. 86:9871-9875.

Jouanin L, Goujon T, de Nadai V, Martin MT, Mila I, Vallet C, Pollet B, Yoshinaga A, Chabbert B, Petit-Conil M, Lapierre C (2000) Lignification in transgenic poplars with extremely reduced caffeic acid 0 -methyltransferase activity. Plant Physiol. 123:1363-1374

Laemmli UK (1970) Cleavage of structure proteins during the assembly of the head of bacteriophage T4. Nature 227:680-685.

Lawrence PK, Koundal KR (2002) Plant protease inhibitors in control of phytophagous insects. Electron. J. Biotechnol. 5:1-17.

Lopes AR, Juliano MA, Juliano L, Terra WR (2004) Coevolution of insect trypsins and inhibitors. Arch. Insect Biochem. Physiol. 55:140-152.

Lowry OH, Rosebrough NJ, Fan AL (1951) Protein measurement with the Folin-phenol reagent. J. Biol. Chem. 193:265-275.

Macedo MLR, Freire MDM, Cabrini EC, Toyama MH, Novello JC, Marangoni S (2003) A trypsin inhibitor from Peltophorum dubium seeds active against pest proteases and its effect on the survival of Anagasta kuehniella (Lepidoptera: Pyralidae). Biochim. Biophys. Acta 1621:170-182.

Macedo MLR, Garcia VA, Freire MGM, Richardson M (2007) Characterization of a Kunitz trypsin inhibitor with a single disulfide bridge from seeds of Inga laurina (SW.) Willd. Phytochemistry 68:1104-1111.

Moreira FMS, Silva MF, Faria SM (1992) Occurrence of nodulation in legume species in the Amazon region of Brazil. New Phytol. 121:563-570.

Morrison JF (1982) The slow-binding and slow, tight-binding inhibition of enzyme catalyzed reactions. Trends Biochem. Sci. 7:102-105.

Oliva MLV, Sampaio MU (2009) Action of plant proteinase inhibitors on enzymes of physiopathological importance. An. Acad. Bras. Ciênc. 81(3):615-621.

Oliveira AS, Migliolo L, Aquino RO, Ribeiro JKC, Macedo LLP, Andrade LBS, Bemquerer MP, Santos EA, Kiyota S, Sales MP (2007) Purification and characterization of a trypsin-papain inhibitor from Pithecelobium dumosum seeds and its in vitro effects towards digestive enzymes from insect pests. Plant Physiol. Biochem. 45:858-865.

Pace CN (1990) Conformational stability of globular proteins. Trends Biochem. Sci. 15:14-17.

Pennington TD (1997) The genus Inga botany; The Royal Botanic Gardens: Kew.

Radisky ES, Kwan G, Karen Lu CJ, Koshland De Jr (2004) Binding, proteolytic, and crystallographic analyses of mutations at the protease-inhibitor interface of the subtilisin BPN'/chymotrypsin inhibitor 2 complex. Biochem. 43:1364813656 .

Reed BJ, Chandler DS, Sandeman RM (1999) Aminopeptidases as potential targets for the control of the Australian sheep blowfly Lucilia cuprina. Int. J. Parasitol. 29:839-850.

Richardson JE, Pennington RT, Pennington TD, Hollingsworth PM (2001) Rapid diversification of a species-rich genus of neotropical rain forest trees. Science 293:2242-2245.

Ryan CA (1989) Proteinase inhibitor gene families: strategies for transformation to improve plant defenses against herbivores. Bioessays 10:20-24.

Ryan CA (1990) Proteinase inhibitors in plants: genes for improving defenses against insects and pathogens. Annu. Rev. Phytopath. 28:425-449.

Santoro MM, Bolen DW (1992) A test of the linear extrapolation of unfolding free energy changes over an extended denaturant concentration range. Biochemistry 31:4901-4907.

Sin SF, Yeung EC, Chye ML (2006) Down-regulation of Solanum americanum genes encoding proteinase inhibitor II causes defective seed development. Plant J. 45:58-70.

Solomon M, Belenghi B, Delledonne M, Menachem E, Levine A (1999) The involvement of cysteine proteases and protease inhibitor genes in the regulation of programmed cell death in plants. Plant Cell 11:431-443.

Teles RCL, Calderon LA, Medrano FJ, Barbosa JARG, Guimarães BG, Santoro MM, Freitas SM (2005) pH Dependence thermal stability of a chymotrypsin inhibitor from Schizolobium parahyba seeds. Biophys. J. 88:3509-3517.

Teles RCL, Souza EMT, Calderon LA, Freitas SM (2004) Purification and $\mathrm{pH}$ stability characterization of a chymotrypsin inhibitor from Schizolobium parahyba seeds. Phytochemistry 65:793-799.

Xavier-Filho J (1992) The biological roles of serine and cysteine proteinase inhibitors in plants. Rev. Bras. Fisol. Veg. 4:1-6.

Yeh KW, Lin MI, Tuan SJ, Chen YM, Lin CY, Kao SS (1997) Sweet potato (Ipomoea batatas) trypsin inhibitors expressed in transgenic tobacco plants confer resistance against Spodoptera litura. Plant Cell Rep. 16:696-699.

Zavala JA, Patankar AG, Gase K, Hui D, Baldwin IT (2004) Manipulation of endogenous trypsin proteinase inhibitor production in Nicotiana attenuata demonstrates their function as antiherbivore defenses. Plant Physiol. 134:1181-1190. 